\title{
Green turtle head trauma with intracerebral hemorrhage: Image diagnosis and treatment
}

\author{
Traumatismo craniano com hemorragia intracerebral em tartaruga verde: diagnóstico \\ por imagem e tratamento
}

\author{
Daphne Wrobel Goldberg, ${ }^{\mathrm{I} \text {,II }}$ Alex Adeodato ${ }^{\mathrm{III}}$ Daniella Torres de Almeida ${ }^{\mathrm{II}}$ \\ Leandro Gomes Corrêa" Juçara Wanderlinde II
}

\begin{abstract}
Sea turtles are threatened to the point of extinction. ABSTRACT The major goal of rehabilitating injured individuals is to eventually reintroduce them back into their habitat. Sea turtles are vulnerable to anthropogenic effects, and impact traumas are a common cause of death among these animals. Carapace and skull fractures are usually related to vessel collisions or propeller impacts. However, intentional traumas inflicted by humans are also considered as a potential threat. The purpose of this article is to describe the diagnosis and rehabilitation procedures of a juvenile green turtle (Chelonia mydas) after severe head trauma with brain hemorrhage. The data presented here can be used as a reference for future cases of head trauma in chelonians.
\end{abstract}

Key words: brain injury, Chelonia mydas, green turtle, head trauma, sea turtle.

\section{RESUMO}

Tartarugas marinhas são animais ameaçados de extinção. Por isso, o principal objetivo em reabilitar individuos feridos é posteriormente reintroduzi-los em seu habitat. Quelonios marinhos apresentam grande vulnerabilidade a efeitos antropogênicos, e a ocorrência de traumatismos impactantes constituem uma importante causa de óbitos entre esses animais. Fraturas de carapaça e crânio estão normalmente associadas a colisões por embarcações. No entanto, lesões intencionais provocadas por humanos também podem ser consideradas ameaças em potencial. O objetivo deste estudo é descrever o diagnóstico e a reabilitação de um indivíduo jovem de tartaruga verde (C. mydas) após traumatismo craniano severo com hemorragia cerebral. Os dados apresentados poderão ser utilizados como referências para casos futuros de traumatismos afetando a região da cabeça de quelônios.
Palavras-chave: Chelonia mydas, lesão cerebral, tartaruga verde, tartaruga marinha, traumatismo craniano.

Accidents involving propeller or hull impact are a common cause of injury and death among sea turtles. Like all reptiles, sea turtles have lungs and need to surface periodically in order to breathe. This behavior leaves them vulnerable to vessel collisions and propeller strikes. Basking juveniles are also predisposed to boat strikes, as they feed in shallow water relatively close to the shore. Moreover, fishermen may deliberately traumatize sea turtles presumed to have decreased catches or damaged gear (MCARTHUR et al., 2004).

Impact trauma often results in serious lacerations, fractures of the skull and carapace, and limbs amputation (ORÓS et al., 2005). Severe head trauma may cause brain injuries and may also damage salt glands, affecting their normal function (GEORGE, 1997). If injuries do not kill the turtle immediately, they may cause debilitation, disorientation, and persistent deficits, thus hindering the turtle's ability to feed or escape from predators.

'Departamento de Bioquímica, Universidade Estadual do Rio de Janeiro (UERJ). Av. 28 de setembro, 87 Fds, 4o andar, Vila Isabel, 20551-030, Rio de Janeiro, RJ, Brasil. Autor para correspondência.

"Fundação Centro Brasileiro de Proteção e Pesquisa das Tartarugas Marinhas (Fundação Pró-Tamar), Campos dos Goytacazes, RJ, Brasil.

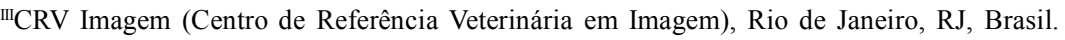


The consequences of cerebral damage secondary to head trauma, are dependent of the type of injury as well as the seriousness of the trauma (OERTEL et al., 2002). Primary brain injury can be followed by secondary brain damage as the result of disturbances in cerebral blood flow and metabolism (CERNAK, 2005). Intracerebral hemorrhage occurs most frequently in cerebral contusions, and it is associated with intracranial pressure elevations (QUAYLE et al., 1997). Although early diagnosis and treatment of individuals with head trauma improves the morbidity and mortality associated with any intracranial injury, for many turtles presented to rehabilitation centers, the most humane course of action is euthanasia.

This study aims to describe the rehabilitation of a juvenile green turtle (C. mydas) after a severe head trauma with brain hemorrhage. It also reports, for the first time in Brazil, the utilization of a computed tomography scanner in the evaluation of brain damage extent in a sea turtle. It is important to emphasize that sea turtles are endangered species, and the major goal of rehabilitating injured individuals is to eventually reintroduce them back into their habitat.

A juvenile $\boldsymbol{C}$. mydas of undetermined sex was found stranded on November $4^{\text {th }}$, in 2008 , on Tatagiba beach, São Francisco do Itabapoana municipal district, Rio de Janeiro State, Brazil. The turtle had a depressed skull fracture involving the right side of the skull. Bone fragments were pushed towards the brain, characterizing a penetrating head injury. On admission, the animal was measured $(36 \mathrm{~cm}$ curved carapace length, $33 \mathrm{~cm}$ curved carapace width), weighed $(3 \mathrm{~kg})$, and received a thorough physical examination. The turtle was in poor body condition, malnourished and emaciated. Clinical signs included dehydration, anorexia, and limb areflexia accompanied by prostration and an apathetic-lethargic state. Furthermore, the salt gland secretion on the right eye had a gelatinous consistency and was thicker than on the left eye.

The animal was housed in the rehabilitation facilities of Bacia de Campos Station (Projeto TAMARICMBio), in Campos dos Goytacazes municipal district, Rio de Janeiro State, Brazil. Initially the turtle was maintained out of the water, placed into a dry fiberglass container padded with foam, to prevent drowning. A light coating of vaseline ointment was applied all over the carapace, head and flippers to avoid dehydration and to prevent the shell from drying out. In order to restore organic perfusion, hypertonic saline solution $\left(15 \mathrm{ml} \mathrm{kg}^{-1} ; \mathrm{NaCl} 7,5 \%\right)$ and dexamethasone ${ }^{\mathrm{a}}\left(2 \mathrm{mg} \mathrm{kg}^{-1}\right)$ were administered intravenously (IV) through a catheter placed in the dorsal cervical sinus, which runs lateral and parallel to the muscular ridges in the dorsal neck region (MCARTHUR et al., 2004). Moreover, furosemide ${ }^{\mathrm{b}}\left(2.5 \mathrm{mg} \mathrm{kg}^{-1}\right)$ was administered IV to reduce intracranial pressure. The wound was cleaned and flushed with sterile saline and iodine $10 \%$ and covered with gentamicin ointment $t^{\mathrm{c}}$. Foreign debris was carefully removed from the fracture site. A neurologic examination was performed to evaluate neurological deficits. General activity, movement, hind and front limb movement, cloacal reflex, pupillary function and eyelid reflex were observed. The animal showed limb areflexia, absence of cloacal reflex and diminished eyelid reaction. Eight days after arrival, the turtle was placed in a $250 \mathrm{~L}$ tank half-filled with fresh water, maintained at $28^{\circ} \mathrm{C}$. During the first two weeks, the following treatment protocol was administered: intravenous fluids q24h $\left(25 \mathrm{ml} \mathrm{kg}^{-1}\right.$; one part Lactated Ringers Solution, 2 parts $2.5 \%$ glucose and $0.45 \%$ sodium chloride), enrofloxacin ${ }^{\mathrm{d}}$ BID (5mg kg-1), dexamethasone q24h $\left(1 \mathrm{mg} \mathrm{kg}^{-1}\right)$ and injectable vitamin supplement $\mathrm{q} 24 \mathrm{~h}\left(5 \mathrm{mg} \mathrm{kg}^{-1}\right)$. A variety of food items were offered (e.g., fish, crab, shrimp, squid and algae) however, the turtle didn't eat by his own and little clinical improvement was observed. In order to avoid weight loss, tube feeding was started on the $5^{\text {th }}$ day of treatment. The turtle was tube fed BID with a fish gruel prepared with ground fish (herring), $20 \mathrm{ml}$ of water, $5 \mathrm{ml}$ of fish oil, and $100 \mathrm{ml}$ of whipping cream. To minimize the risk of regurgitation and aspiration, the animal was placed back in the water as soon as the procedure was over.

Thirteen days later, the turtle was brought to the CRV Imagem (Reference Veterinary Center of Image), in Barra da Tijuca, Rio de Janeiro, for computed tomography (CT) of the head. The exam was performed in order to better characterize the lesion and evaluate the full extent of the damage. No sedation/anesthesia was required, since the turtle was extremely lethargic, however, in order to prevent further injury the animal was placed on a foam pad and fixed on the table with sticking plasters. CT scan was obtained with a helical CT scanner (GE Hispeed $\mathrm{Lxi}^{\mathrm{TM}}$ ). The slice thickness was $2 \mathrm{~mm}$ at $120 \mathrm{kV}, 1 \mathrm{~s}$ scanning and $150 \mathrm{~mA}$. The images were submitted afterwards to multi-planar and 3D reconstructions. Craniocaudal and lateral radiographs were also taken to evaluate the lungs by means of digital radiography (FUJI Computed Radiography; FCR Capsula XL), since respiratory disease is often common in chelonians (MCARTHUR et al., 2004).

Evaluation of the CT images revealed a depressed fracture of the right region of the splanchnocranium, including frontal, postorbital, and parietal bones as well as intracerebral hemorrhage (Figure $1 \& 2$ ). It is probable that skull fragments may have caused impact injury to underlying cerebral 
parenchyma, resulting in brain contusion. The parietal and postorbital fragments were deeply depressed, compressing the right salt gland and possibly increasing the thickness of its secretion.

Although a surgical intervention based on the CT findings was considered (NAGANOBU et al., 2000), conservative treatment was initially instituted in order to improve the turtle's condition before surgery. Initial antibiotics were replaced by amikacin sulfate ${ }^{f}$

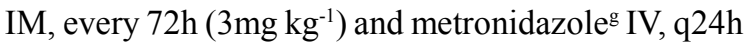
$\left(20 \mathrm{mg} \mathrm{kg}^{-1}\right)$ for broader spectrum. After two weeks, a significant clinical improvement was observed. The turtle had a weight gain of $1.3 \mathrm{~kg}$ and, was then, transferred to a 2,000L fiberglass tank filled with salt water, maintained at $27^{\circ} \mathrm{C}$. The $\boldsymbol{C}$. mydas became more active, begun to eat fish (herring) and algae on her own, and signs of healing were clearly noticed. The turtle was tagged with Inconel metal tags on the front flippers (\# BR58131, BR58132) and released back into the wild on February $27^{\text {th }}$ in 2009 at Farol de São Thomé, Campos dos Goytacazes.

Animals facing severe head trauma acquire high probability of dying or having permanent brain damage. For this reason, early diagnosis and appropriate treatment increases life expectancy and may minimize brain injuries. Many of the neurologic examination techniques used to evaluate domestic animals can be adapted for the evaluation of sea turtles. An accurate assessment of the animal along with complementary exams allows a precise diagnosis. Regardless of which treatment option is chosen, the animal should not experience pain or discomfort, and if this is no possible, euthanasia must be considered.

The data presented here can be used as a reference for future cases of head trauma in chelonians, even though it seems unlikely that the diagnosis and treatment of a single animal would contribute to species conservation.

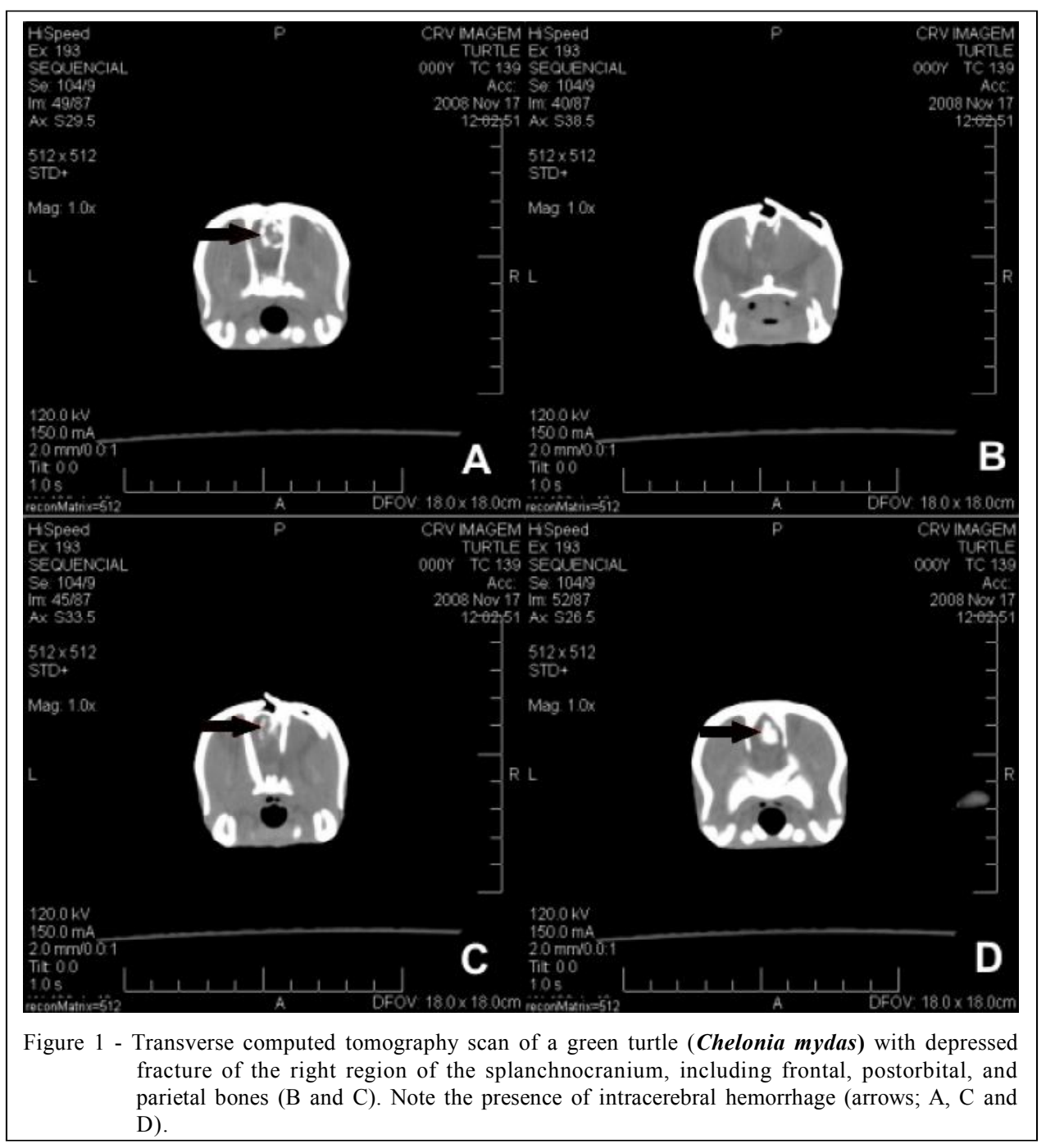

Ciência Rural, v.40, n.11, nov, 2010. 


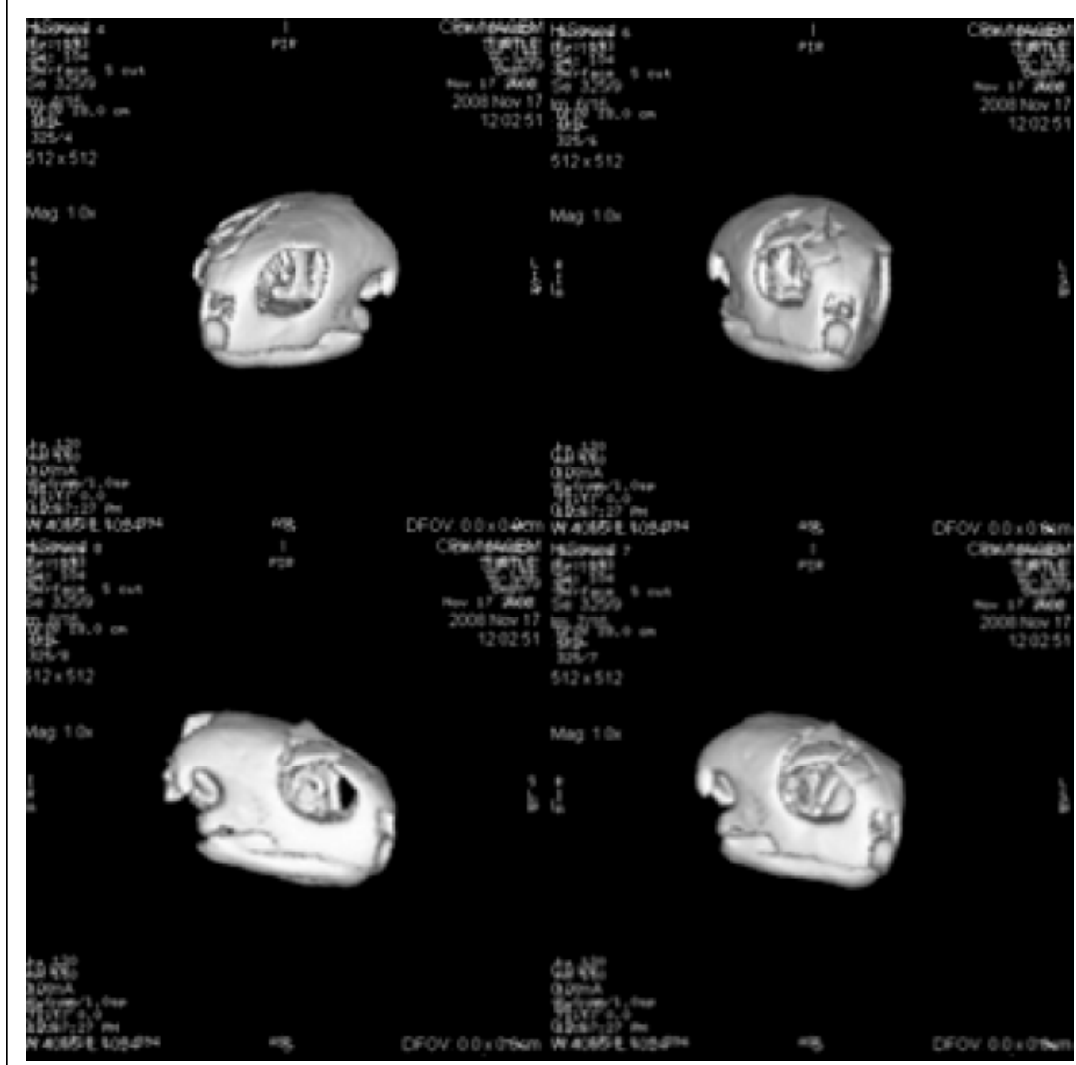

Figure 2 - Three-dimensional reconstruction of the computed tomography scan of the head. Green turtle (Chelonia mydas) showing skull fracture on the right side of the head.

\section{SOURCES}

a - Dexavet ${ }^{\circledR}$, Laboratório Bravet Ltda., 20950-340, Rio de Janeiro, RJ, Brazil.

b - Lasix ${ }^{\circledR}$, Sanofi-Aventis Farmacêutica Ltda., 08613-010, Suzano, SP, Brazil.

c - Garamicina ${ }^{\circledR}$, Mantecorp, São Paulo, SP, 04699-970, Brazil. d - Flotril $10 \%{ }^{\circledR}$, Indústria Química Farmacêutica ScheringPlough S.A., 04714-002, São Paulo, SP, Brazil.

e - Bionew ${ }^{\circledR}$, Vetnil Indústria e Comércio de Produtos Veterinários Ltda., 13290-970, Louveira, SP, Brazil.

f - Novamin ${ }^{\circledR}$, Bristol-Myers Squibb, 04743-903, São Paulo, SP, Brazil.

g - Flagyl ${ }^{\circledR}$, Sanofi-Aventis Farmacêutica Ltda., 08613-010, Suzano, SP, Brazil.

\section{ACKNOWLEDGMENTS}

The authors thank CRV Imagem, Projeto TAMARICMBio, R. Braga, M. Caldas, G. Dutra, R. Simon, P. Fleury, C. Baptistotte, V. Bastos, J. Bastos and R. Dias.

\section{REFERENCES}

CERNAK, I. Animal models of head trauma. Journal of the American Society for Experimental NeuroTherapeutics, v.2, n.3, p.410-422, 2005. Available from: <http://
www.ncbi.nlm.nih.gov/pmc/articles/PMC1144485/pdf/ neurorx002000410.pdf $>$. Accessed: aug 10, 2009. doi:10.1602/ neurorx.2.3.410.

GEORGE, R.H. Health problems and diseases of sea turtles. In: LUTZ, P.L.; MUSICK, J.A. The biology of sea turtles. Florida: CRC LLC, 1997. Cap.14, p.363-386.

MCARTHUR, S. et al. Anatomy and physiology. In: MCARTHUR, S. et al. Medicine and surgery of tortoises and turtles. Oxford: Blackwell, 2004. Cap.3, p.35-71.

NAGANOBU, K. et al. Surgical repair of a depressed fracture in a green sea turtle, Chelonia mydas. Journal of Veterinary Medical Science, v.62, n.1, p.103-104, 2000.

OERTEL, M. et al. Progressive hemorrhage after head trauma: predictors and consequences of the evolving injury. Journal of Neurosurgery, v.96, n.1, p.109-116, 2002. Available from: $<$ http://www.ncbi.nlm.nih.gov/pubmed/11794591>. Accessed: Aug 10, 2009. doi: 10.3171/jns.2002.96.1.0109.

ORÓS, J. et al. Diseases and causes of mortality among sea turtles stranded in the Canary Islands, Spain (1998-2001). Diseases of aquatic organisms, v.63, n. 1, p.13-24, 2005.

QUAYLE, K.S. et al. Diagnostic testing for acute head injury in children: when are head computed tomography and skull radiographs indicated? Pediatrics, v.99, n.5, p.e11, 1997. Available from: http://pediatrics.aappublications.org/cgi/ content/full/99/5/e11. Accessed: Aug 10, 2009. doi: 10.1542/ peds.99.5.e11. 